\title{
The Relationship between Academic Procrastination and Self-control in Entrepreneurship Education
}

\author{
Lili Marliyah $^{1, *}$, Della Arny Novera ${ }^{2}$, Dwi Asih Kumala Handayani ${ }^{1}$, Fuad Abdillah ${ }^{3}$, Kasidi Kasidi ${ }^{1}$ \\ ${ }^{1}$ Faculty of Teacher Training and Education, Ivet University, 50235, Gajahmungkur, Indonesia \\ ${ }^{2}$ Faculty of Economic and Business, Diponegoro University, Tembalang, 50275, Semarang, Indonesia \\ ${ }^{3}$ Faculty of Science and Technology, Ivet University, 50235, Gajahmungkur, Indonesia
}

Received September 28, 2020; Revised December 2, 2020; Accepted December 13, 2020

\section{Cite This Paper in the following Citation Styles}

(a): [1] Lili Marliyah, Della Arny Novera, Dwi Asih Kumala Handayani, Fuad Abdillah, Kasidi Kasidi , "The Relationship between Academic Procrastination and Self-control in Entrepreneurship Education," Universal Journal of Educational Research, Vol. 8, No. 12B, pp. 8471 - 8477, 2020. DOI: 10.13189/ujer.2020.082656.

(b): Lili Marliyah, Della Arny Novera, Dwi Asih Kumala Handayani, Fuad Abdillah, Kasidi Kasidi (2020). The Relationship between Academic Procrastination and Self-control in Entrepreneurship Education. Universal Journal of Educational Research, 8(12B), 8471 - 8477. DOI: 10.13189/ujer.2020.082656.

Copyright@2020 by authors, all rights reserved. Authors agree that this article remains permanently open access under the terms of the Creative Commons Attribution License 4.0 International License

\begin{abstract}
Procrastination is related to academic achievement, student health, and emotional well-being in which academic procrastination represents an irrational delay. This behavior is often considered dangerous and even described as an endemic phenomenon. This study aimed to examine theories and case studies on the relationship between academic procrastination and self-control in entrepreneurship education. The subjects were students of SMA Negeri 3 Semarang majoring in Natural Sciences who acquired entrepreneurship education. The data were gathered through a simple random sampling technique using a questionnaire. The results showed that self-control had a negative relationship with academic procrastination. The level of academic procrastination of class XI Science SMA N 3 Semarang on entrepreneurship education was in the medium category of $54.3 \%$. The self-control of class XI Science SMA N 3 Semarang in the entrepreneurship education was at a high level as indicated by the average percentage of all indicators of 64\%. Entrepreneurship education that prioritizes optimal self-control and reduces academic procrastination is expected to create better quality human resources.
\end{abstract}

Keywords Academic Procrastination, Self-control, Entrepreneurship, Education

\section{Introduction}

Unemployment has become a structural problem for Indonesian society. Many things become causal factors. Those originated from internal aspects such as soft skills, attitudes, mentality, capital conditions, disabilities and others as well as external factors such as quality of education, economic system, a political system of a country, and other factors [1]. According to Statistics Indonesia (BPS), the unemployment rate in Indonesia in 2013 was still high at $6.01 \%$. It decreased in 2017 by $4.57 \%$ but then increased by $5.28 \%$ in 2019 . Meanwhile the unemployment rate in Semarang City in 2014, 2015, 2017, and 2019 were $7.76 \%, 5.77 \%, 6.61 \%$, and 5.29\% respectively [2].

The market demand is increasing in line with the more competitive world of work due to globalization and modernization. It results in various innovations as well as requires better individual competence. It is essential to improve the individual's competence to reflect national ability and identity. Great independence and competitiveness will be able to create individuals who figure out the way to produce and develop something more creative.

The education sector must be able to create and develop programs that are relevant to current market developments or demand. In line with this, [3] Hazraini argued that entrepreneurial motivation is a motivating factor for someone to make something new and different from 
others or from what already exists creatively and innovatively so that it becomes a person's stimulus to be creative. The motivation results in something creative and innovative.

Academic procrastination is a behaviour of delaying on academic activities and prevents a person from achieving optimal performance resulting in emotional, physical and academic consequences. Academic procrastination problems usually occur in students for several reasons. Those who do so are called procrastinators. Maladaptive behaviour (academic procrastination) tends to persist and perpetuate itself so that it becomes difficult to change [4] [5]. It is difficult for students to reflect on learning. Therefore, it is enigmatic to see the value and motivation to learn on their own [6].

There is a tendency the more difficult and requires independence the assignment is, the more often students to procrastinate. It explains why many students delayed doing entrepreneurial assignments. Based on the observations on students of SMA N 3 Semarang, the level of academic procrastination in a similar case was $54.3 \%$ (Primary Data, 2019) which was at the high level. Therefore, students who postpone entrepreneurial assignments also experience low levels of self-control.

Self-control is the individual's ability to make self-regulation, which means determining priorities in starting and carrying out entrepreneurial assignments, therefore paying more attention to the long-term consequences. Self-control acts as a mediator in impulsive correlation and procrastination [7]. Self-control is a more complex variable and has a large capacity to provide positive changes in a person's life. In line with this study, [7] there was an initial survey that showed a significant negative correlation between academic procrastination and self-control. Several studies of failure of self-control as a cause of delay also agreed with the result (e.g. [8] [9] [10] [11] [12] [13] [14]. Temporal Motivation Theory (TMT) is the best theoretical framework for explaining dynamics delay [15].

Hence, there is a need for studies that measure individual factors because TMT does not play a sufficient role in explaining self-control and performing general procrastination relationship tasks [7]. This study is to find out the relationship between academic procrastination and self-control, especially in entrepreneurship education.

\section{Materials and Methods}

It was a quantitative correlational study conducted on students of class XI Science SMA N 3 Semarang acquiring entrepreneurship education. The data collection techniques used were questionnaires, documentation, and observations. A questionnaire is a form of data collection instrument that is relatively easy and flexible. This study employed a Likert scale consisting of Strongly Agree (SS),
Agree (S), Neutral (N), Disagree (TS), and Strongly Disagree (STS) answers. On the other hand, documentation is a technique for obtaining related information or data in the form of archives, documents or reports. The documentation used in this study included a list of student names, student learning outcomes in entrepreneurship education, and school profiles. Observation is a way of collecting data through observing. In this study, the activity observed was the teaching and learning process of entrepreneurship. The sampling technique used a random sampling then analysed by Pearson's product-moment correlation analysis in SPSS 18.0 for windows.

Indicators used to measure academic procrastination variables [16] included delays in starting and completing assignments, delays in doing assignments, time gaps between plans and actual performance as well as doing more enjoyable activities. Indicators of self-control variables [16] in students are the ability to control behaviour, the ability to control the stimulus, the ability to anticipate events or incidents, the ability to interpret events or incidents and the ability to make decisions. The normality test using the Kolmogorov-Smirnov showed a statistical significance of 0.569 so that the academic procrastination data were normally distributed. The results of the $\mathrm{X} 1$ and $\mathrm{Y}$ linearity test obtained a statistical significance of 0.299 with an $\mathrm{F}$ value of 1.203. Therefore, the Self-Control Variables (X1) and Academic Procrastination $(\mathrm{Y})$ have a significant linear relationship.

\section{Results and Discussion}

Academic procrastination is an endemic phenomenon [17], with prevalence rates often reported to be between $50 \%$ and $70 \%$ and sometimes higher [9]. The subjects of the study were students of class XI Science SMA N 3 Semarang in entrepreneurship education. The samples were 65 respondents in total consisting of 46 women (71\%) and 19 men (29\%). Based on educational background, as many as 16 respondents (24.6\%) were from private junior high schools while 49 respondents (75.4\%) were from public junior high schools. Based on age, there were 3 people (4.6\%) were 15 years old, 45 people $(69.2 \%)$ were 16 years old, 16 people $(24.6 \%)$ were 17 years old, and 1 person (1.5\%) was 19 years old.

Hypothesis testing was conducted to determine the relationship between academic procrastination and self-control using product moment analysis. Based on Table 1 shows that the results of the Karl Pearson moment product test analysis show the hypothesis "There is a significant negative relationship between self-control and academic procrastination in students of class XI Science SMA N 3 Semarang in entrepreneurship education" which is declared acceptable. Partially, the higher students' self-control towards entrepreneurship education learning, 
the lower the level of student academic procrastination in carrying out entrepreneurial assignments.

Table 1. Results of Self Control Relations with Academic Procrastination

\begin{tabular}{cccc}
\hline \multicolumn{4}{c}{ Correlations } \\
\hline & KD & Y \\
\hline \multirow{4}{*}{ KD } & Pearson Correlation & 1 & $-.361^{* *}$ \\
& Sig. (2-tailed) & & .003 \\
& $\mathrm{~N}$ & 65 & 65 \\
\hline \multirow{3}{*}{$\mathrm{Y}$} & Pearson Correlation & $-.361^{* * *}$ & 1 \\
& Sig. (2-tailed) & .003 & \\
& $\mathrm{~N}$ & 65 & 65 \\
\hline
\end{tabular}

**. Correlation is significant at the 0.01 level (2-tailed).

Source: Primary Data, 2019.

Figure 1 shows that the academic procrastination variable in the medium category (54.3\%) which is formed based on the activity shift indicator (doing more enjoyable activities) has the largest average, namely 59.05\%. Meanwhile, the delay behaviour indicator (delay in starting and completing assignments) of $56.2 \%$, the time gap indicator (time gap between the plan and actual performance) is $56.2 \%$, the lowest contribution indicator is the delay in doing the task of $44.9 \%$. The level of self-control variable in Figure 2 shows a high category (64.04\%) which is formed based on anticipation indicators (ability to control a stimulus) of $65.8 \%$, interpretive indicators (ability to interpret events or incidents) by $65 \%$, decision indicators (ability to make a decision) by $63.1 \%$, and the lowest contribution indicator was the behaviour indicator (ability to control behaviour) at 56.1\%.

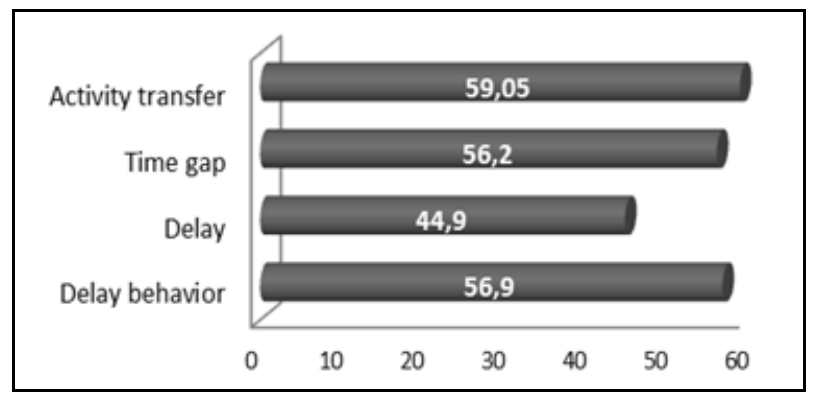

Figure 1. Percentage of Academic Procrastination Based on Indicators

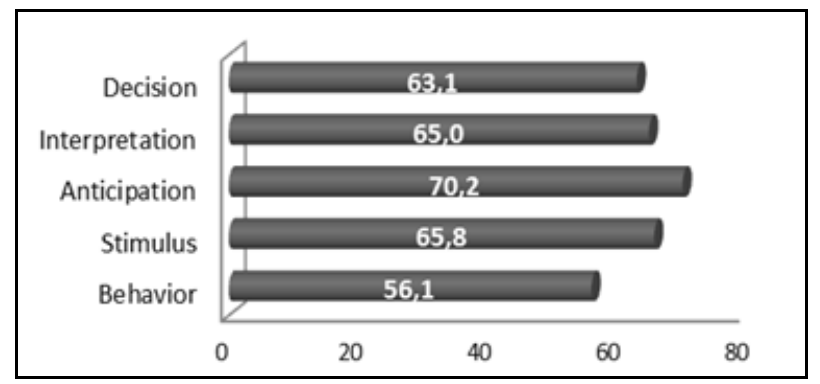

Figure 2. Percentage of Self Control Based on Indicators

Academic procrastination is a type of delay carried out for official assignments related to academic type [18]. There are two types of procrastination, namely dysfunctional procrastination in which not purposeful and detrimental to procrastination and functional delay in which accompanied by powerful but not counterproductive reasons [16]. This study led to dysfunctional procrastination. Procrastination is not only a delay component but also delay scheduled assignments, priorities or main things to do [19]. Procrastination refers to the tendency to leave or delay or thoroughly avoid completing activities under individual control [12]. Delay exhibits several characteristics such as traits [20] [22], perhaps that successful interventions require a more intensive and prolonged treatment program to produce measurable increases in academic delay. Procrastination behaviour includes the difference between the planned and the actual hours of study [22] [23] [24].

The results showed that the level of academic procrastination of class XI Science SMA N 3 Semarang on entrepreneurship education was at the medium level. It was indicated by the average percentage of all indicators at $54.3 \%$. A person is said to do procrastination if showing characteristics such as fear of failure, impulsive, perfectionist, indifferent, and procrastinating and thus exceeds due time [25].

The finding of the average percentage for each indicator is in line with the procrastination characteristics [16]. It explained that the activity shift indicator (doing more enjoyable activities) has the largest average of 59.05\%. Students deliberately postpone their assignments and do something more enjoyable. The delay behaviour indicator has an average of $56.9 \%$. It was a delay in starting or completing work on existing assignments. Despite starting and finishing the assignment, a procrastinator tends to delay the work even it is useful.

The time gap indicator (time gap between plans and actual performance) has an average of $56.2 \%$. Procrastinator has difficulty running the task process within the specified time limit. The lowest contribution was the indicator of delay (delay in doing assignments) that has an average of $44.9 \%$. Procrastinators take longer than the time required in general. They spend their time preparing themselves over time, doing things that are not necessary to complete assignments and ignoring time limits. Previous research has linked the degree of procrastination with different types of actions associated with goal attainment [26] [27], individual differences increase the frequency of self-control [28], and actual learning behaviour [29] [26].

The main variable in this study was the students' academic procrastination behaviour. Areas in academic procrastination include written assignments, exams preparations, reading assignments per week, administrative assignments, academic assignments, and meetings [30]. The writing assignments students procrastinate consist of paper assignments, essays, 
entrepreneurial case studies, business road map (business canvas model). On the other hand, students also procrastinate in activities such as studying for chapters, midterm tests, final semester exams, quizzes, competitions, and other exams. The reading technique assignments are indeed different from each individual. Administrative assignments may include paying tuition fees, filling out attendance lists, copying or making school records. In addition, academic assignments can take the form of general academics. Moreover, delay in meetings can be a delay in entering the classroom, discussions, training, etc.

Two factors someone procrastinates are namely psychological factors and physical factors [31]. Psychological factors include low self-esteem, surrender, lack of consistency, anxiety and the desire to get the best results by procrastinating. Meanwhile, physical factors include the inability of a person to control external stimuli which causing procrastination.

Procrastination has a consequential impact as reducing one's productivity level. It can also damage one's mental, work ethic and reduce the level of human resources quality [31]. Academic procrastination has even been described as an endemic phenomenon [17], with reported prevalence rates often between $50 \%$ to $70 \%$ and sometimes even higher [9].

Academic procrastination can interfere with students' mastery of assignments leading to impaired academic achievement of these students [32]. The reason for procrastinating due to buying time and postponing the duties and obligations is one of the unpreparedness that still occurs today [33]. Students' characteristics who have high academic procrastination are the lack of ability to manage time which results in unfinished assignments and poor management of learning time. As a result, students do not understand the learning material and do not have maximum readiness when facing exams. The phenomenon is due to different adjustment of the new task levels between individuals and socioeconomic status. Academic procrastination symbolizes an irrational and often dangerous type of procrastination in which procrastination is negatively related to a students' academic performance, health, and emotion (e.g. [34] [35] [26] [36] [37] [38].

As expected, a large number of studies support the idea of failure to self-control as a cause of procrastination (e.g. [39] [40] [41] [12] [13] [42]. There is a negative relationship between procrastination and self-control [9]. Self-control has a large capacity to provide positive changes in one's life [7]. The level of self-control of class XI Science SMA N 3 Semarang in the entrepreneurship education is at the high level as indicated by the average percentage of all indicators of $64 \%$. One of the factors that reduce procrastination is self-control which has a large capacity to provide positive changes in one's life [7]. Metacognitive self-regulation has been identified as an important predictor of academic achievement [43]. Procrastination is associated with worse academic achievement, including lower assignment scores, course grades, and average grades [26] [44] [17] [14].

The reinforcement here is a rule that determines in what conditions or when reinforcement will be delivered. Most of human social behaviour is formed and maintained by non-permanent reinforcement [45]. Skinner also noted that schedules of reinforcement are categorized into two basic dimensions, namely: (1) reinforcement is given only after a person has passed the pause (interval reinforcement), and (2) reinforcement is given only after a person has demonstrated the number of responses (ratio reinforcement) [45]. On the other hand, procrastination is also a state that is measured over time during a semester [9], across academics [23] [46] [36].

This finding explains that the indicator of anticipation (ability to anticipate events or incidents) has the largest average of $70.2 \%$, while the indicator of stimuli (ability to control stimuli has an average of $65.8 \%$. The ability to adjust the stimuli (stimuli modifiability) is the ability to know how and when an unwanted stimulus is encountered. Interpretation indicator (ability to interpret events or incidents) has an average of $65 \%$. It means the individual's ability to process unwanted information by interpreting, assessing, or relating events in a cognitive framework as a psychological adaptation or stress reduction. This aspect consists of several components, namely obtaining information (information gain) and conducting assessments. The decision indicator (decision-making ability) has an average of $63.1 \%$. Controlling decisions is a person's ability to choose an outcome or action based on something believed or agreed on. Self-control in making choices will function, whether with the opportunity, freedom or the possibility of the individual to choose various possible actions. The lowest contribution indicator is the behaviour indicator (ability to control behaviour) which has an average of 56.1\%.

If procrastination is carried out continuously because of a maladaptive pattern, there will be a failure of self-control and eventually will lead to procrastination [9]. A low level of self-control refers to an individual's inability to do something and ignore the long-term consequences. Therefore a poor self-control attitude may increase the level of students' academic procrastination in entrepreneurship education. On the contrary, if the students' self-control is at a high level, it will decrease the academic procrastination level in entrepreneurship education. In this case, self-control in class XI Science students SMA N 3 Semarang reduces the academic procrastination. Here there is a very significant negative relationship between self-control and procrastination [47] [48].

Based on the theory of reinforcement and previous studies, self-control also determines how a person behaves as determining what to control in doing something. All behaviours controlled by internal reinforcement tend to stimulate intrinsic motivation as achievement motivation. 
The discussion above provides a significant negative relationship between self-control and academic procrastination. Middle school students are particularly prone to procrastination. It corroborates previous findings which reveal that other than the parents, young people tend to procrastinate. [26] [49] [14].

The hypothesis which mentions "There is a significant negative relationship between self-control and student academic procrastination in entrepreneurship education in class XI Science SMA N 3 Semarang" is accepted. It showed the value of 0.361 at a moderate level with a significance value $(\rho)$ of 0.003 . According to the examiner's criteria, the results were significant. In the SPSS output research, the results were not equal to 0.361 with negative parameters. It means that any decrease in academic procrastination is due to the high increase in students' self-control. Therefore, students' self-control of class XI Science in entrepreneurship education can reduce the level of academic procrastination on student entrepreneurial assignments. Students generally procrastinate more in some domains of life [36] and some types of academics [50] [46], given that procrastination is considered irrational procrastination [17] [51].

The relationship test that is declared valid for all predetermined populations, namely all 65 students of class XI Science, can be seen through the results of significance. Based on data processing, the significance value was $0.003<0.05$ meaning the results were significant. It concluded that there is a negative and significant relationship between self-control and academic procrastination in entrepreneurship education of students of class XI Science SMA N 3 Semarang.

Temporal Motivation Theory (TMT) attempts to explain one's decision to procrastinate choosing processes [52]. TMT shows that everyone always prioritizes activities that promise the highest utility within a given time. In other words, a person tends to procrastinate when they perceive low utility as doing a task. Meanwhile, self-control is the individual's ability to override or change unwanted thoughts, emotions, impulses, temptations, and behaviours that can have positive consequences. Self-control also has a significant negative role in academic procrastination in middle school students [53]. It provides a strong indication that self-control is inversely related to academic procrastination [54] [55] [56]. Moreover, there is a moderate positive relationship between religious values, social skills, honesty and self-control [57].

Someone who procrastinates generally lack in self-control [39]. There is a significant correlation between self-control and academic procrastination among students in the Psychology Study Program at Unesa [58]. Self-control contributed $48.5 \%$ to the occurrence of academic procrastination among students [58]. Future studies are needed to test whether the perception of procrastination can change after receiving grades for academic tasks (e.g. examinations, papers, assignments) [59].

\section{Conclusion}

Based on the results of the data analysis, the self-control has a moderate negative significant relationship to academic procrastination in SMA $\mathrm{N} 3$ Semarang students. The results of data analysis also showed that the level of academic procrastination of class XI Science SMA N 3 Semarang on entrepreneurship education was in the medium category as indicated by the average percentage of all indicators of $54.3 \%$. To overcome the problems of learning entrepreneurship education and to be optimal, the role of self-control in students is needed. The level of self-control of class XI Science SMA N 3 Semarang in the entrepreneurship education is at the high level as indicated by the average percentage of all indicators of $64 \%$.

This study implies that any decline in academic procrastination is due to a high level of students' self-control. Therefore, it is necessary to have an attitude of self-control in class XI Science students in entrepreneurship education to reduce/suppress academic procrastination level on student entrepreneurial assignments. The most dominant indicator that is prone to procrastination is the students' shifting activities. Meanwhile, self-control considerably contributes to the high anticipation of students towards certain situations. Therefore, with an increase in self-control followed by a decrease in students' academic procrastination in entrepreneurship education can help improve students' weak mentality due to lazy behaviour. The make use of abilities effectively and productively specifically in positive activities, helps to initiate skilful Indonesian youth generation.

\section{REFERENCES}

[1] Novianti, E. Kesenjangan Gender Tingkat Pengangguran Terbuka Di Indonesia, Jurnal Pendidikan dan Ekonomi, Vol. 8, No. 2, 166-174, 2019

[2] BPS, Badan Pusat Statistik. Indeks Pembanguanan Manusia 2017. Jakarta: BPS, 2018

[3] Hazraini, Tanjung. Pengaruh Pembelajaran Kewirausahaan dan Motivasi Kewirausahaan Terhadap Minat Menjadi Pengusaha pada Mahasiswa Program Studi Manajemen Fakultas Ekonomi Dan Bisnis Usu, 2017.

[4] Katz, I., Eilot, K., \& Nevo, N. "I'll do it later”: Type of motivation, self-efficacy and homework procrastination, Motivation and Emotion, Vol. 38, No. 1, 111-119, 2014.

[5] Onatsu-Arvilommi, T., Nurmi, J. E., \& Aunola, K. The development of achievement strategies and academic skills 
during the first year of primary school, Learning and Instruction, Vol. 12, No. 5, 509-527, 2002.

[6] Sørensen, K. B., \& Davidsen, H. M. A Holistic Design Perspective on Entrepreneurship Education, Universal Journal of Educational Research, Vol. 5, No. 10, 1818-1826, 2017.

[7] Ursia, N.R., Siaputra, I.B. and Sutanto, N. Academic Procrastination and Self Control in Thesis Writing Students of Faculty of Psychology Universitas Surabaya, Makara Seri Sosial Humaniora, Vol. 17, No. 1, 1-18, 2013.

[8] Balkis, M., \& Duru, E. Procrastination, self-regulation failure, academic life satisfaction, and affective well-being: Underregulation or misregulation form, European Journal of Psychology of Education, 2015.

[9] Janssen, J. Academic procrastination: Prevalence among high school and undergraduate student and relationship to academic achievement (doctoral dissertation), Georgia State University, 2015.

[10] Sims, C. M. Self-regulation coaching to alleviate student procrastination: Addressing the likeability of studying behaviours, International Coaching Psychology Review, Vol. 9, No. 2, 147-164, 2014.

[11] Tan, C. X., Ang, R. P., Klassen, R. M., Yeo, L. S., Wong, I. Y. F., Huan, V. S., \& Chong, W. H. Correlates of academic procrastination and students' grade goals, Current Psychology, Vol. 27, No. 2, 135-144, 2008.

[12] Tuckman, B. W. Relations of academic procrastination, rationalization, and performance in a web course with deadlines, Psychological Reports, Vol. 96, 1015-1021, 2005.

[13] Van Eerde, W. Procrastination: Self-regulation in initiating aversive goals, Applied Psychology, An International Review, Vol. 49, No. 3, 372-389, 2000.

[14] Van Eerde, W. A meta-analytically derived nomological network of procrastination, Personality and Individual Differences, Vol. 35, 1401-1418, 2003.

[15] Siaputra, I. B. Temporal Motivation Theory: Best Theory (Yet) To Explain Procrastination, ANIMA Indonesian Psychological Journal, Vol. 25, No. 3, 206-214, 2010.

[16] Ghufron, M.N \&Risnawati R. Teori-Teori Psikologi, Jogjakarta, Ar-Ruzz Media, 2016.

[17] Steel, P. The nature of procrastination: A meta-analytic and theoretical review of quintessential self-regulatory failure, Psychological Bulletin, Vol. 133, No. 1, 65-94, 2007.

[18] Ferrari, J. Self Handicapping by Procrastinator: Protecting Self-Esteem Social Esteem, or Both?, Journal Research In Personality, Vol. 25, No.2, 245-261, 1995.

[19] Steel, P. D. G. The Measurement and Nature of Procrastination, Thesis, University of Minnesota, 2002.

[20] Schouwenburg, H. C., \& Lay, C. H. Trait procrastination and the big-five factors of personality, Personality and Individual Differences, Vol. 18, 481-490, 1995.

[21] Steel, P. The nature of procrastination: A meta-analytic and theoretical review of quintessential self-regulatory failure, Psychological Bulletin, Vol. 133, No. 1, 65-94, 2007.
[22] Gustavson, D. E., \& Miyake, A. Academic procrastination and goal accomplishment: A combined experimental and individual differences investigation, Learning and individual differences, Vol. 54, 160-172, 2017.

[23] Dewitte, S., \& Schouwenburg, H. C. Procrastination, temptations, and incentives: The struggle between the present and the future in procrastinators and the punctual, European Journal of Personality, Vol. 16, 469-489, 2002.

[24] Steel, P., Brothen, T., \& Wambach, C. Procrastination and personality, performance, and mood. Personality and Individual Differences, Vol. 30, 95-106, 2001

[25] Knaus, W.J. The Procrastination Workbook: Your Personalized Program for Breaking Free from The Patterns That Hold You Back, New Harbinger, 2002.

[26] Kim, K. R., \& Seo, E. H. The relationship between procrastination and academic performance: A meta-analysis, Personality and Individual Differences, Vol. 82, No. 26-33, 2015.

[27] Morris, P. E., \& Fritz, C. O. Conscientiousness and procrastination predict academic coursework marks rather than examination performance, Learning and Individual Differences, Vol. 39, 193-198, 2015.

[28] Gröpel, P., \& Steel, P. A mega-trial investigation of goal setting, interest enhancement, and energy on procrastination, Personality and Individual Differences, Vol. 45, 406-411, 2008.

[29] Glick, D. M., \& Orsillo, S. M. An investigation of the efficacy of acceptance-based behavioral therapy for academic procrastination, Journal of Experimental Psychology: General, Vol. 144, 400-409, 2015.

[30] Andika, F.R. Faktor-Faktor yang Mempengaruhi Perilaku Menunda Tugas Akademik Mahasiswa Program Studi Pendidikan Teknik Bangunan FT UNP, Statistika, No.6, Hal 3, 2015

[31] Srantih, T. Pengaruh Perfeksionisme terhadap Prokrastinasi Akademik pada Mahasiswa yang Sedang Mengerjakan Skripsi di Fakultas Psikologi UIN Sunan Gunung Djati Bandung, Psympathic, Vol. 1, No.1, 58-68, 2016.

[32] Ananda, N.Y., \& Mastuti, E. Pengaruh Perfeksionisme Terhadap Prokrastinasi Akademik Pada Siswa Program Akselerasi, Jurnal Psikologi dan Pendidikan, 2013.

[33] Safa’ati, E., Halim, M. I., \& Iliyati, Z. Peran Regulasi Diri dan Prokrastinasi Akademik Mahasiswa Universitas Muria Kudus, Jurnal Fakultas Psikologi Universitas Muria Kudus, Vol. 2, No. 1, 75-84, 2017.

[34] Grunschel, C., Patrzek, J., \& Fries, S. Exploring different types of academic delayers: A latent profile analysis, Learning and Individual Differences, Vol. 23, 225-233, 2013.

[35] Jackson, T., Weiss, K. E., Lundquist, J. J., \& Hooper, D. The impact of hope, procrastination, and social activity on academic performance of midwestern college students, Education, Vol. 124, No. 2, 310-320, 2003.

[36] Klingsieck, K. B. Procrastination in different life-domains: Is procrastination domain specific?, Current Psychology, Vol. 32, 175-185, 2013. 
[37] Minnaert, A. E. M. G., \& Janssen, P. J. Bias in the assessment of regulation activities in studying at the level of higher education, European Journal of Psychological Assessment, Vol. 13, No. 2, 99-108, 1997.

[38] Tice, D. M., \& Baumeister, R. F. Longitudinal study of procrastination, performance, stress, and health: The costs and benefits of dawdling, Psychological Science, Vol. 8, No. 6, 454-458, 1997.

[39] Balkis, M., \& Duru, E. Procrastination, self-regulation failure, academic life satisfaction, and affective well-being: Underregulation or misregulation form, European Journal of Psychology of Education, 2015

[40] Sims, C. M. Self-regulation coaching to alleviate student procrastination: Addressing the likeability of studying behaviours, International Coaching Psychology Review, Vol. 9, No. 2, 147-164, 2014.

[41] Tan, C. X., Ang, R. P., Klassen, R. M., Yeo, L. S., Wong, I. Y. F., Huan, V. S., \& Chong, W. H. Correlates of academic procrastination and students' grade goals, Current Psychology, Vol. 27, No. 2, 135-144, 2008.

[42] Wolters, C. A. Understanding procrastination from a self-regulated learningperspective, Journal of Educational Psychology, Vol. 95, No. 1, 179-187, 2003.

[43] Bakracevic Vukman, K., \& Licardo, M. How cognitive, metacognitive, motivational and emotional self-regulation influence school performance in adolescence and early adulthood. Educational Studies, Vol. 36, No.3, 259-268, 2010 .

[44] Richardson, M., Abraham, C., \& Bond, R. Psychological correlates of university students' academic performance: A systematic review and meta-analysis, Psychological Bulletin, Vol. 138, 353-387, 2012.

[45] Uno, H. B. Orientasi Baru dalam Psikologi Pembelajaran, Jakarta, Bumi Aksara, 2008.

[46] Ozer, B. U., Demir, A., \& Ferrari, J. R. Exploring academic procrastination among Turkish students: Possible gender differences in prevalence and reasons, The Journal of Social Psychology, Vol. 149, 241-257, 2009.

[47] Endriyanto, C. Hubungan Antara Self Control dan Prokrastinasi Akademik Berdasarkan TMT, Jurnal Ilmiah Mahasiswa Universitas Negeri Surabaya, Vol. 3, No.1, 1-11, 2014.

[48] Aini, A. N., \& Mahardayani, I. H. Hubungan antara Kontrol Diri dengan Prokrastinasi dalam Menyelesaikan Skripsi pada Mahasiswa Universitas Muria Kudus, Jurnal Psikologi UMK: PITUTUR, Vol 1, No. 2, 65-71, 2011.

[49] Ziegler, N., \& Opdenakker, M. C. The development of academic procrastination in firstyear secondary education students: The link with metacognitive self-regulation, self-efficacy, and effort regulation, Learning and Individual Differences, Vol. 64, 71-82, 2018.

[50] Clark, J. L., \& Hill, O. W. J. Academic procrastination among African-American college students, Psychological Reports, Vol. 75, 931-936, 1994.

[51] Steel, P. Arousal, avoidant and decisional procrastinators: Do they exist? Personality and Individual Differences, Vol. 48, 926-934, 2010.

[52] Siaputra, I. B. Temporal Motivation Theory: Best Theory (Yet) To Explain Procrastination, ANIMA Indonesian Psychological Journal, Vol. 25, No. 3, 206-214, 2010.

[53] Clara, C., Dariyo, A., \& Basaria, D. Peran Self-Efficacy Dan Self-Control Terhadap Prokrastinasi Akademik Pada Siswa Sma (Studi Pada Siswa Sma X Tangerang), Jurnal Muara Ilmu Sosial, Humaniora, dan Seni, Vol. 1, No. 2, 2018.

[54] Komarraju, M., \& Nadler, D. Self-efficacy and academic achievement: Why do implicit beliefs, goals, and effort regulation matter?, Learning and Individual Differences, Vol. 25, 67-72, 2013.

[55] Strunk, K. K., \& Steele, M. R. Relative contributions of self-efficacy, self-regulation, and self-handicapping in predicting student procrastination, Psychological Reports, Vol. 109, No. 3, 983-989, 2011.

[56] Sungur, S. Modeling the relationships among students' motivational beliefs, metacognitive strategy use, and effort regulation, Scandinavian Journal of Educational Research, Vol. 51, No. 3, 315-326, 2007.

[57] Akar, H., \& Dogan, Y. B. The Role of Personal Values in Social Entrepreneurship, Universal Journal of Educational Research, Vol. 6, No.1, 83-90, 2018.

[58] Susanti, E., \& Nurwidawati, D. Hubungan antara kontrol diri dan konformitas Dengan prokrastinasi akademik pada mahasiswa program studi psikologi Unesa. Character, Vol. 2, No. 3, 1-7, 2014.

[59] Kljajic, K., \& Gaudreau, P. Does it matter if students procrastinate more in some courses than in others? A multilevel perspective on procrastination and academic achievement, Learning and Instruction, Vol. 58, 193-200, 2018 